\title{
Public infrastructure investment, economic growth and policy choice: evidence from China
}

\author{
Yu Nannan' ${ }^{1}$ Mi Jianing ${ }^{2}$ \\ ${ }^{\mathbf{1 , 2}}$ School of Management, Harbin Institute of Technology, Harbin, China, 150001 \\ (E-mail: yunannan1201@163.com)
}

\begin{abstract}
The relationship between public infrastructure investment and economic growth has always been an eye-catching issue for China since Chinese governments have devoted most of public funds to financing infrastructure after the economic reform. Taking the Chinese infrastructure investment policy as the background, this paper aims to examine the effect of infrastructure investment on economic growth. The paper establishes a gross productive equation about the contribution of productive elements on economic growth based on C-D production function and estimates the output elasticity of every productive element. Both theoretic and practical analysis indicates that infrastructure capital stock exerts a positive impact on economic growth and it will increase long-term economic growth rate, which could verify the appropriateness of the current 'infrastructure-stressed' investment policies of the Chinese government.
\end{abstract}

Keywords: public infrastructure; economic growth; policy choice; China

\section{Introduction}

There has been a long-running debate on (and increasing interest in) the effects of infrastructure on regional growth and economic performance. During the 1970s and 1980s, the United States had undergone a dramatic slowdown in national productivity growth. Yet, public infrastructure was seldom mentioned as a major factor in this slowdown. Mostly the studies were focused on energy prices, social and economic regulation, and low levels of capital accumulation. Only later, with discussions of economic decline during this period, would there be associations with declining public infrastructure investment. Researchers then paid considerable attention to the possible effects of public infrastructure on state as well as national productivity.

Aschauer's (1989) work spurred research on the effects of public infrastructure. He found that public infrastructure was an important input into the national production function, and argued for greater spending on public capital. After this, large numbers of empirical studies on the effects of public infrastructure were spawned. However, the findings from empirical search also prompted some controversies. Because it is difficult to find a consensus, mainly due to the uses of different data, varying estimation techniques, variable types of infrastructures and peculiar geographic scales of analysis [1].

After the economic reform policy in 1978, China has undergone an explosive economic growth, however, it is necessary for public policy to evaluate the contribution of different factors to economic growth in China. Based on the practice of other countries, we should pay special attention to the effect of infrastructure capital.

There has no consensus on the definition of infrastructure. The general definition means infrastructure includes transport, telecommunications, water, energy and waste disposal which is usually regarded as "physical infrastructure"[2]. The broadest concept of infrastructure contains both "physical infrastructure" and "social infrastructure" like education and maintenance of environmental quality [3].

These infrastructures provide the basic framework for a nation to support essential public services in order to get higher economic growth and a better quality of life. In this research, literature on infrastructure just focuses on the "physical infrastructure".

This study presents an empirical investigation of the relationship between infrastructure investment and economic growth in China using a dataset for a 20 -year period, 1988-2007. The purpose of the research is to 
study the impact of the public infrastructure investment on economic growth in China, Output flexibility. A correlation model between the public infrastructure capital and the economic growth will be constructed. The study also tries to work out the output elasticity of the infrastructure investment by statistic analysis. It's necessary and remarkably important for Chinese government to the policy decision-making.

\section{Methodology}

world. Foreign scholars often take empirical investigation on this topic by $\mathrm{C}-\mathrm{D}$ production function approach, shown in Table 1. The infrastructure capital is considered as a factor to aggregate production function in order to study public infrastructure capital's effort to economic growth by estimating output elasticity and contribution rate of infrastructures.

\begin{tabular}{|c|c|c|c|c|}
\hline Researcher & $\begin{array}{c}\text { Research } \\
\text { subject }\end{array}$ & Model & Data & $\begin{array}{l}\text { Output } \\
\text { elasticity }\end{array}$ \\
\hline $\begin{array}{l}\text { Munnell and } \\
\text { Cook } \\
(1990)\end{array}$ & $\begin{array}{c}48 \text { states of } \\
\text { America }\end{array}$ & $\begin{array}{l}\text { C-D production } \\
\text { function }\end{array}$ & time series data, $1949-87$ & $\begin{array}{l}0.31- \\
0.39\end{array}$ \\
\hline $\begin{array}{l}\text { Aschauer } \\
\text { (1990) }\end{array}$ & $\begin{array}{l}50 \text { states of } \\
\text { America }\end{array}$ & $\begin{array}{l}\text { C-D production } \\
\text { function }\end{array}$ & $\begin{array}{c}\text { Cross section data, } \\
1965-1983\end{array}$ & $\begin{array}{c}0.055- \\
0.11\end{array}$ \\
\hline $\begin{array}{l}\text { Merriman } \\
(1990)\end{array}$ & $\begin{array}{l}9 \text { regions of } \\
\text { Japan }\end{array}$ & Translog & Panel data, 1954-1963 & $\begin{array}{c}0.43- \\
0.58\end{array}$ \\
\hline $\begin{array}{l}\text { Tatom } \\
(1991)\end{array}$ & America & $\begin{array}{l}\text { C-D production } \\
\text { function }\end{array}$ & Time series data, 1949-1989 & insignificant \\
\hline $\begin{array}{l}\text { Ford and Poret } \\
\qquad(1991)\end{array}$ & $\begin{array}{l}11 \text { OECD } \\
\text { nations }\end{array}$ & $\begin{array}{l}\text { C-D production } \\
\text { function }\end{array}$ & Time series data & $\begin{array}{l}\text { Some nations } \\
\text { significant; }\end{array}$ \\
\hline $\begin{array}{l}\text { Ford and Poret } \\
\qquad(1991)\end{array}$ & America & $\begin{array}{l}\text { C-D production } \\
\text { function }\end{array}$ & Time series data & $\begin{array}{c}0.39- \\
0.54\end{array}$ \\
\hline $\begin{array}{c}\text { Munnell } \\
\text { (1993) }\end{array}$ & $\begin{array}{l}48 \text { states of } \\
\text { America }\end{array}$ & $\begin{array}{l}\text { C-D production } \\
\text { function }\end{array}$ & Panel data, 1964-1988 & $\begin{array}{c}0.14- \\
0.17\end{array}$ \\
\hline $\begin{array}{l}\text { Toen-Gout and } \\
\text { Jon-geling(1994) }\end{array}$ & Netherland & $\begin{array}{l}\text { C-D production } \\
\text { function }\end{array}$ & Time series data, 1963-1988 & 0.37 \\
\hline Wylie(1995) & Canada & natural logarithm & Time series data, 1946-1991 & $\begin{array}{c}0.11- \\
0.52\end{array}$ \\
\hline $\begin{array}{c}\text { Canning } \\
\text { (1998) }\end{array}$ & 57 nations & $\begin{array}{l}\text { C-D production } \\
\text { function according } \\
\text { different types }\end{array}$ & Panel data, 1960-1990 & $\begin{array}{l}\text { Different result } \\
\text { according types }\end{array}$ \\
\hline $\begin{array}{l}\text { Duggall et al. } \\
\quad(1999)\end{array}$ & America & Nonlinear functions & Time series data, 1960-1989 & 0.27 \\
\hline Ligthart(2001) & Portuguese & $\begin{array}{l}\text { C-D production } \\
\text { function }\end{array}$ & Time series data, 1985-1995 & $\begin{array}{l}\text { Positive } \\
\text { significant }\end{array}$ \\
\hline $\begin{array}{l}\text { Cadot et } \\
\text { al.(2002) }\end{array}$ & France & $\begin{array}{c}\text { C-D production } \\
\text { function and policy } \\
\text { equation }\end{array}$ & $\begin{array}{c}\text { Time series data, } 1985-1992( \\
\text { Transportation } \\
\text { infrastructure) }\end{array}$ & 0.08 \\
\hline $\begin{array}{l}\text { Calderon \& } \\
\text { serven } \\
(2002)\end{array}$ & 101 nations & $\begin{array}{l}\text { C-D production } \\
\text { function }\end{array}$ & Panel data, 1960-1997 & 0.16 \\
\hline $\begin{array}{l}\text { Stephan } \\
\text { (2004) }\end{array}$ & Germany & $\begin{array}{l}\text { C-D production } \\
\text { function }\end{array}$ & Time series data, 1979-1996 & 0.38 \\
\hline $\begin{array}{c}\text { Everaert\& } \\
\text { Heylen }(2005)\end{array}$ & Belgium & $\begin{array}{c}\text { Translog } \\
\text { production function }\end{array}$ & Time series data, 1965-2004 & 0.31 \\
\hline Kamps（2006） & $\begin{array}{c}22 \text { OECD } \\
\text { nations }\end{array}$ & $\begin{array}{l}\text { C-D production } \\
\text { function }\end{array}$ & $\begin{array}{c}\text { Time series data and panel } \\
\text { data, 1960-2004 }\end{array}$ & 0.22 \\
\hline
\end{tabular}

Table 1: Main research projects and results using production function approach

In last years, Chinese scholars have focused on the theory and empirical research on the relationship between infrastructure investment and economic growth, some of whom also have got much great achievement using international advanced research method. S. Ma analyzed public capital stock's effect to private sector by econometrics model, and the output elasticity of public capital from 1981 to 1998 is 0.55 in "an empirical research on the relationship between 
public capital and the economic growth in private sector" (2000). H. Lou took an empirical investigation on "public infrastructure investment and long-term economic growth" (2003). The study considered the public capital as a factor to economic growth model and constructed endogenous investment and exogenous investment infrastructure capital stock economic growth model based on Ramsey Model. The output elasticity of infrastructure capital is 0.2347. J. Fan published several research papers about this question and the issues estimated the output elasticity of infrastructure capital by C-D production function approach and CES production function approach. The infrastructure output elasticity got 0.695 and its ridiculous high.

Based on the analysis frame of production function, this study estimates the output elasticity of infrastructure capital in China. The service supplied by infrastructure capital is regarded as a factor production, and bought in aggregate production function with capital and labor. Due to the analysis frame consisted by theses three factors, we can examine the relationship between infrastructure capital and economic development. The normal production function including labor, infrastructure capital and other capital can be written as:

Where:

$$
Y t=\mathrm{A} a \cdot \mathrm{F}\left(\mathrm{L} t{ }^{\prime} \mathrm{K} t^{\prime} G t^{\prime}\right)
$$

- $\mathrm{Y}_{\mathrm{t}}$ is the real GDP;

- $\mathrm{L}_{\mathrm{t}}$ is the number of total labor;

- $\mathrm{K}_{\mathrm{t}}$ is the capital stock of non-infrastructure;

- $\mathrm{G}_{\mathrm{t}}$ is the capital stock of infrastructure;

- $\mathrm{A}_{\mathrm{t}}$ is the total factor productivity.

In this research, the production function is regarded as Cobb-Douglas production function:

$$
Y_{t}=A_{t} L_{t}^{\alpha} K_{t}^{\beta} G_{t}^{\gamma}
$$

In the function, $\alpha, \beta, \gamma$ represents the output elasticity of labor, infrastructure capital and non-infrastructure.

Taking the log of the both sides of the eq. (2), we have the following (3):

$$
\begin{aligned}
& L n_{Y t}=L n_{\mathrm{A}_{t}}+\alpha L n_{\mathrm{L}_{t}}+\beta L n_{\mathrm{K}_{t}}+\gamma L n_{\mathrm{G} t} \\
& \qquad{ }^{L n_{Y t}}=L n_{A_{t}}+(1-\beta-\gamma) L n_{L t}+\beta L n_{K_{t}}+\gamma L n_{G_{t}}
\end{aligned}
$$

Equally:

The production techniques encompass constant returns to scale and variable (increasing and decreasing) returns to scale. The present study tests two hypotheses under the two kinds of condition. Firstly, it is assumed that production technique maintains constant returns to scale, pertaining to all investment factors. Under this condition, $\alpha+\beta+\gamma=1$, and if we substitute $\alpha=1-\beta-\gamma$ into eq.(3), we have:

Secondly, it is presumed that the non-infrastructural factors have constant returns to scale, and all of the investment factors have increasing returns to scale. Under this condition, $\alpha+\beta=1$, and if we substitute $\alpha=1-\beta$ into eq.(3), we have:

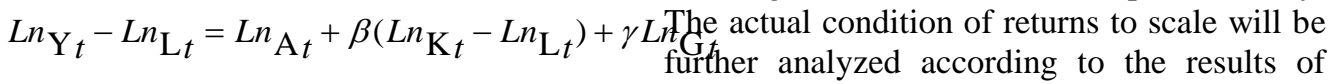

\section{Data and variable measurement}

Data of Chins for a 20 year's period, from 1988-2007, is adopted for our analysis, main statistical sources include: regression.

(1)National Statistical Bureau (various years),

The $\ln A t$ in eq.(5) is represented as a constant term, and is represented as a time trend variable in eq. (6), which are the frequently dealing methods. In addition, taking the normal distributed random disturbance term, we have a final regression formula for the present study. China Statistical Yearbook, Beijing, China, China Statistical Yearbook Press

(2)National statistical bureau, department of comprehensive statistics. 2008, Comprehensive statistical data and materials on 55 years of new China, Beijing, China, China statistics press 
(3)National Statistical Bureau , National GDP historical summary

Data sources: 1. Real GDP data are calculated on the basis of the ones in China Statistical Yearbook of the twenty years; the numbers of labor are gleaned from China Statistical Yearbook of the twenty years. 2 . Three fields of infrastructure are taken into consideration: the production and supply of electricity, gas and water, the management of water and the communication industry of transportation, storage, postal service and telecommunication. By virtue of the limitation of the statistics at hand, the above table only lists the state-owned investment in permanent assets of those three industries, and it is assumed that the state-owned investment represents all investment in those fields for the state-owned capital plays the major part of infrastructure investment.

\begin{tabular}{ccccc}
\hline Year & GDP & Labor Number & Infrastructure capital & Non-infrastructure capital \\
1988 & 4425 & 43043 & 1393.9 & 8484.8 \\
1989 & 4823.7 & 44510 & 1471.2 & 9020.6 \\
1990 & 5349.2 & 45865.5 & 1578.6 & 9644.2 \\
1991 & 6161 & 47316.5 & 1725.1 & 10483.3 \\
1992 & 6990 & 49035 & 1949.8 & 11643.5 \\
1993 & 7610.6 & 50577.5 & 2214.7 & 13008.1 \\
1994 & 8491.3 & 52032.5 & 2507.2 & 14620.2 \\
1995 & 9448 & 53558.5 & 2790.1 & 16431.2 \\
1996 & 9832.2 & 54831.5 & 3012.1 & 17765.9 \\
1997 & 10209.1 & 60039 & 3290.7 & 18892.2 \\
1998 & 11147.7 & 65120 & 3636.8 & 20226.6 \\
1999 & 12735.1 & 65821.5 & 4057.6 & 22106.8 \\
2000 & 14452.9 & 66480 & 4631.1 & 24690.6 \\
2001 & 16283.1 & 67131.5 & 5365.4 & 27763.2 \\
2002 & 17993.7 & 67760 & 6168.9 & 31152.4 \\
2003 & 19718.7 & 68507.5 & 7118.1 & 34774.4 \\
2004 & 21099.5 & 69385 & 8211.7 & 38476 \\
2005 & 23139.9 & 70228.5 & 9750.4 & 42465.5 \\
2006 & 24792.5 & 71015.5 & 11311.4 & 46590.6 \\
2007 & 26774.9 & 71739.5 & 12928.7 & 51126.8 \\
\hline & & & & \\
\hline
\end{tabular}

Table 2: data of major variables for production function

\section{Analyses on Measurement Result}

Here an OLS regression exercise is employed to demonstrate the model above by Eviews4.1.In order to eliminate autocorrelation of residuals, we add in AR1 and AR2 to the regression. Owing to the regression result of the time-trend is insignificant, the time-trend item is not contained in the final equation. Table 3 and Table4 show the final regression results corresponding the equation (5) and equation (6). 


\begin{tabular}{llllc}
\hline Variables & $\begin{array}{l}\text { Regression } \\
\text { coefficient }\end{array}$ & $\begin{array}{l}\text { Standard } \\
\text { deviation }\end{array}$ & T value & P value \\
C & -1.059713 & 0.321500 & -3.296148 & 0.0058 \\
LnK-LnL & -0.330196 & 0.243656 & -1.355173 & 0.1984 \\
LnG-LNL & 1.394749 & 0.329035 & 4.238903 & 0.0010 \\
AR(1) & 1.157051 & 0.176326 & 6.562014 & 0.0000 \\
AR(2) & -0.679050 & 0.162840 & -4.170041 & 0.0011 \\
R-squared & 0.998327 & $\begin{array}{l}\text { Mean dependent } \\
\text { var }\end{array}$ & -1.573743 \\
Adjusted & 0.997812 & $\begin{array}{l}\text { S.D.dependent } \\
\text { R-squared }\end{array}$ & 0.355609 \\
$\begin{array}{l}\text { S.E. of } \\
\text { regression }\end{array}$ & 0.016635 & $\begin{array}{l}\text { Akaike info } \\
\text { criterion }\end{array}$ & -5.124423 \\
Sum squared & 0.003598 & Schwarz criterion & -4.877097 \\
$\begin{array}{l}\text { Lesid lilekihood } \\
\text { Surbin-Watson }\end{array}$ & 51.11981 & F-statistic & 1938.813 \\
stat & 2.410953 & Prob(F-statistic) & 0.000000 \\
\hline
\end{tabular}

Table 3: OLS regression result of constant returns to scale

\begin{tabular}{llllr}
\hline Variables & $\begin{array}{l}\text { Regression } \\
\text { coefficient }\end{array}$ & $\begin{array}{l}\text { Standard } \\
\text { deviation }\end{array}$ & T value & P value \\
C & -3.488652 & 1.712583 & -2.037070 & 0.0625 \\
LnK-LnL & 0.602096 & 0.137768 & 4.370359 & 0.0008 \\
LnG & 0.297193 & 0.134933 & 2.202526 & 0.0463 \\
AR(1) & 1.112309 & 0.196318 & 5.665842 & 0.0001 \\
AR(2) & -0.621377 & 0.184492 & -3.68035 & 0.0050 \\
R-squared & 0.985750 & $\begin{array}{l}\text { Mean dependent } \\
\text { var }\end{array}$ & 1.093430 \\
Adjusted & 0.981366 & $\begin{array}{l}\text { S.D.dependent } \\
\text { var }\end{array}$ & 0.164267 \\
$\begin{array}{l}\text { R-squared } \\
\text { S.E. of regression }\end{array}$ & 0.022424 & $\begin{array}{l}\text { Akaike info } \\
\text { criterion }\end{array}$ & -4.527278 \\
$\begin{array}{l}\text { Sum squared } \\
\text { resid }\end{array}$ & 0.006537 & $\begin{array}{l}\text { Schwarz } \\
\text { criterion }\end{array}$ & -4.279952 \\
Log lilekihood & 45.74550 & F-statistic & 224.8272 \\
$\begin{array}{l}\text { Durbin-Watson } \\
\text { stat }\end{array}$ & 1.896214 & Prob(F-statistic) & 0.000000 \\
\hline
\end{tabular}

Table 4: OLS regression result of increasing returns to scale

In the condition of constant returns scale, the regression result is illogical. The variable coefficient and significance don't match economic law or can't be explained very well to much extent. In the condition of increasing returns scale, each variable is rational and the equation has a high goodness of fittest, which means the estimated result is ideal. The regressive result is:

$$
Y_{t}=0.0305 L_{t}^{0.3979} K_{t}^{0.6021} G_{t}^{0.2972}
$$

is the rate of increase while infrastructure capital increases 1\%) , $\beta$ is 0.2972; The outputelasticity of non-infrastructure capital, $\gamma$ is 0.6021 ; the output elasticity of labor, $\alpha$ is 0.3979. Chinese output elasticity of infrastructure capital, which is lower than private capital, has a significant economic growth effect. Infrastructure capital increases $1 \%$ can obtain $0.2972 \%$ extra total output. 
According to the regression result above, the output elasticity of infrastructure capital (which

The empirical results suggest that physical infrastructure development contribute positively to Chinese economic growth. In this context, China's aggressive investment (around $15 \%$ of GDP) on infrastructure is justified to sustain growth and minimize the impact of global financial crisis. The contribution of investment to growth reflects the investment-oriented growth strategy followed by China. However, indeed the non-infrastructure capital can lead to a much higher growth, which means a package of investment policies is needed for Chinese economic growth. Non-infrastructure includes private sector capital and social welfare capital. Some literature has proved that the investment in health and education is most crucial for growth in China. And this result suggests that it is necessary to design an economic policy that improves the human capital formation as well as physical infrastructure for sustainable economic growth in developing countries. The results pointed out the Chinese government chose the right policy choice, justifying why China has been heavily spending on infrastructure (both physical and social infrastructure) development since early nineties.

\section{Conclusions}

The development of the infrastructure construction in China adopted the 'lagging pattern' for a long period like most other developing countries. Since the foundation of the People's Republic of China, the investment in the infrastructure have not been expanded until the development of the economy was obviously subjected to the infrastructure, or until the marginal benefit produced by the investment in the infrastructure was far more than the benefit brought by other investment.

With the implementation of the Eighth and Ninth Five Year Plan of the China's central government, and especially with the promotion of the positive fiscal policy which was carried out in 1998, the infrastructure industry has been undergoing rapid development which drastically changed the supply and services of China's infrastructure. However, the development of this kind is barely a 'making up' for the great gap between the lagging condition and the need of the economy.
According to the present study, the development of the infrastructure is still lagging between the demands of the economy. A large body of foreign and Chinese studies has shown that the infrastructure plays a positive role of promoting the economy development in the long run. Moreover, the promoting effect of the infrastructure to the economy is the dominant factor in the interaction between the infrastructure and the economic growth.

As a result, we strongly suggest China adopt the policy that developing in the same pace as a whole, while allowing a few parts to develop faster than the needed, in the case of the construction of the infrastructure.

\section{References}

[1] Aschauer, D.A., "Is public expenditure productive?" Journal of Monetary Economics, 1989, pp.177-200

[2] Aschauer, D.A., "Public investment and productivity growth in the group of seven," Economic Perspectives, 1989, pp.17-25

[3] Duggal, V.G.S., "Infrastructure and productivity: a nonlinear approach,” Journal of Econometrics, 1999, pp.47-74

[4] Lynde C. and J. Richmond, "The Role of Public Capital in Production," Review of Economics and Statistics,1992, pp.37-44

[5] Holtz-Eakin, "public sector capital and the productivity puzzle," Review of Economics and Statistics, 1994,pp.12-21

[6] Duffy-Deno, K.T. and R.W.Eberts, "Public infrastructure and regional economic development: A simultaneous equation approach," Journal of urban economics, 1991, pp.329-343

[7] $\mathrm{Hu}$, A. and Y. Xiong, "Regional disparity in knowledge development in China: characteristics, causes, and solutions,"(in Chinese) Management World, 2005, pp.18-26

[8] Hulten, C.R., "Is there too little public capital? Infrastructure and economic growth," American Enterprise Institute Discussion Paper.

[9] International Monetary Foundation, China:economic performance and policy challenges,IMF and NCAER Conference

[10] Li, S. T.and F. Zhai, An analysis of the Chinese economy in the next twenty years, Workshop on Economic Growth in China, Beijing, China 
[11] Morrison, C.J., "State infrastructure and productive performance," American Economic Review, 1996, pp.1006-1011

[12] Wang, Y. and Y.D. Yao, "Sources of China's economic growth 1952-2001: incorporating human capital accumulation." China Economic Rewiew, 2004, pp.32-53

[13] Solow, R.M., "A contribution to the theory of economic growth," Quarterly Journal of Economics, 1956, pp.65-84

[14] Caileron, C., and L. Serven, “ The effects of infrastructure development on Growth and income distribution," World Bank Policy Research Working Paper 3400, 2004

[15] Christine Kessides, "Institutional options for the provision of infrastructure," The World Bank, 1993

[16] Christine Kessides, "The contribution of infrastructure to economic development: a review of experience and policy implication," World Bank discussion papers, 1993

[17] Canning, D., "The Contribution of Infrastructure to Aggregate Output," The World Bank Policy Research Working Paper 2246, 1999

[18] Yu, C., "Human Capital and Regional Economic Growth in China," ph.D dissertation, Tsinghua Univerity(in Chinese)

[19] Jonsson, D.K., "The nature of infra-system services," Journal of infrastructure systems, ASCE, 2005, pp.1133-1140

[20] The World Bank, "World development report, Infrastructure for development," The World Bank, Wanshington, D.C, 1994

[21] Wang, E.C., "Public infrastructure and economic growth: a new approach applied to east Asian economics," Journal of Policy Modeling, 2002, pp.411-445

[22] Wallesen, S., "An empirical analysis of competition, privatization, and regulation in African and Latin America," Journal of Industrial Economics XLIX, 2001, pp.1-19

[23] Flores De Frutos, R.a. P., Alfredo, "Public capital and aggregate growth in the United States: Is public capital productive?" University of California at San Diego Discussion Paper, 1990

[24] Tatom, J.A., "Public capital and private sector performance," Federal Reserve Bank of St.Louis Rewiew, 1991, pp.3-12

[25] Friedlaender, A.F., "How does public infrastructure affect regional economic performance?" Discussion. ALICIA H. MUNELL, pp.108-112 